\title{
Jacqueline Baishanski, L'Orient dans la pensée du jeune Camus. L'étranger, un nouvel évangile
}

\section{Emanuele Kanceff}

\section{Q OpenEdition \\ 1 Journals}

\section{Edizione digitale}

URL: http://journals.openedition.org/studifrancesi/35172

DOI: 10.4000/studifrancesi.35172

ISSN: 2421-5856

\section{Editore}

Rosenberg \& Sellier

\section{Edizione cartacea}

Data di pubblicazione: 1 novembre 2005

Paginazione: 450

ISSN: 0039-2944

\section{Notizia bibliografica digitale}

Emanuele Kanceff, «Jacqueline Baishanski, L'Orient dans la pensée du jeune Camus. L'étranger, un nouvel évangile», Studi Francesi [Online], 146 (XLIX | II) | 2005, online dal 30 novembre 2015, consultato il 19 avril 2021. URL: http://journals.openedition.org/studifrancesi/35172 ; DOI: https://doi.org/ 10.4000/studifrancesi.35172

Questo documento è stato generato automaticamente il 19 avril 2021.

\section{(c)}

Studi Francesi è distribuita con Licenza Creative Commons Attribuzione - Non commerciale - Non opere derivate 4.0 Internazionale. 


\title{
Jacqueline Baishanski, L'Orient dans la pensée du jeune Camus. L'étranger, un nouvel évangile
}

\author{
Emanuele Kanceff
}

\section{NOTIZIA}

JACQUELINE BAISHANSKI, L'Orient dans la pensée du jeune Camus. L'étranger, un nouvel évangile, Paris-Caen, Lettres Modernes-Minard («Situation», 56)., 2002, 306 p.

1 Lo studio è formato da una prima parte dedicata alla percezione dell'Oriente nello scrittore e da una seconda parte che si concentra sul romanzo L'Etranger. Dopo aver analizzato il poliedrico indirizzo filosofico-storico del giovane Camus, l'autrice traccia un quadro del fascino dell'Oriente negli anni 1914-1918 e studia poi l'influenza che sul giovane futuro scrittore ebbe il suo maestro Jean Grenier. Anche nelle letture dello studente Camus si rivela l'importanza di questo tema orientale, che lascia tracce nelle opere di giovinezza.

2 Venendo poi specificamente a L'Etranger, Baishanski ne studia la visione dell'uomo e del mondo, l'obiettività e il distacco come moduli creativi, la funzione del silenzio, le caratteristiche che derivano dalle filosofie dell'Asia. Attraverso una successione di brevi scene più giustapposte che concatenate - esemplari come modelli di comportamento in condizioni concrete e definite - il romanzo ci mostra, dice l'autrice, come bisogna vivere al di là dell'assurdità della vita. Questa nuova arte di vita, che deve molto all'Asia, implica particolarmente il distacco da una società convenzionale e teatrale, il rifiuto di un ordine sociale arbitrario e ipocrita, e che ci si sforzi di servire la verità per fare nascere finalmente l'uomo libero, «l'homme qui nous apporterait le salut, ce nouveau saint que cherchait Camus». 